\title{
The Affordable Care Act (Aca) in the Past Decade
}

\author{
Carole Mireille Mende B.D..$^{*}$ Ruth Endam Mbah. ${ }^{2 *}$ \\ Nelson Mandela College of Government \& Social Sciences, \\ Department of Public Policy, Southern University and A\&M, LA, USA. \\ cdonalds@yahoo.comendamruth@yahoo.com²
}

\begin{abstract}
The Affordable Care Act (ACA) refers to two separate pieces of legislation - the Patient Protection and Affordable Care Act (P.L. 111-148) and the Health Care and Education Reconciliation Act of 2010 (P.L. 111152) - that, together expand Medicaid coverage to millions of low-income Americans and makes numerous improvements to both Medicaid and the Children's Health Insurance Program (CHIP). Since the passage of the Affordable Care Act (ACA), commonly known as Obamacare, there have been several attempts to repeal and replace it. This paper details the journey of the Obamacare and outlines the Repeal and Replace attempts on the Affordable Care Act.
\end{abstract}

Keywords: Affordable Care Act, Medicaid, Health Care, Repeal, Replace, Insurance, Legislation

DOI: $10.7176 / \mathrm{HRL} / 51-04$

Publication date: February $29^{\text {th }} 2020$

\section{Introduction.}

Since the passage of the Affordable Care Act (ACA), commonly known as the Obamacare, there have been several attempts in federal courts to challenge the constitutionality of the legislation. Some lawmakers as well as organizations who opposed the passage of the Obamacare took legal actions following its passage. There have been several court challenges involving attempts to invalidate key provisions of the Obamacare. Twenty-eight states filed joint and or individual lawsuits (including 26 states engaged in a joint action) to strike down the Obamacare 's individual mandate. Meanwhile other states were either expected to join the multi-state lawsuit or are considering filing additional independent suits. Several state legislatures were attempting to counteract and prevent elements of the bill within their states. Legislators in 29 states introduced measures to amend their constitutions to void portions of the health care reform law. Thirteen state statutes were introduced to prohibit portions of the law; as a matter of fact, two states already enacted statutory bans (Cauchi, R, 2012). About six legislatures had made attempts to enact bans, but the measures were unsuccessful. A ballot initiative was passed overwhelmingly in Missouri that exempted the state from some provisions of Obamacare. Many Missouri legal analysts expected that the measure will be struck down if challenged in Federal court. The lawsuit states the following legal rationale:

"Regulation of non-economic activity under the Commerce Clause is possible only through the Necessary and Proper Clause. The Necessary and Proper Clause confers supplemental authority only when the means adopted to accomplish an enumerated power are 'appropriate', are 'plainly adapted to that end', and are 'consistent with the letter and spirit of the constitution.' Requiring citizen-to-citizen subsidy or redistribution is contrary to the foundational assumptions of the constitutional compact." (Case 3:10-cv-00188-HEH, Document 1. Page 5) In several press releases, the Attorney General for several states indicated their primary basis for the challenge was a violation of "state sovereignty". Their release repeated the claim challenging the federal requirement under threat of penalty, that all citizens and legal residents have qualifying health care coverage. They also claimed that the law puts an unfair financial burden on the state.

\section{Repeal Attempts on the Affordable Care Act.}

Since the Affordable Care Act (ACA) was passed in 2010, not only States but Congress was also deeply divided over the ACA. Some Lawmakers opposed specific provisions in Obamacare, the entire law has repeatedly been debated upon and considered for a repeal, defund, delay, or otherwise amendment of the law (Jacobs, 2012).

For some Democrats, a more socialized solution for healthcare reform would be to expand Medicare or create something like it, along with Medicaid, to cover everyone in a "single payer" system just like that of Canada. Meanwhile the Right wing (Republican) would prefer a less ambitious law that uses government subsidies mainly to help those people who are not insurable, leaving the rest of the market to function as normal. This 
system would allow insurers to continue medical underwriting practices that screen people for health status and exclude pre-existing conditions. The Affordable Care Act (ACA) was designed to avoid these extremes of the right and left wings by aiming for a middle course that preserves a private insurance market for most people, but at the same time, reforms the market so that it advances rather than undermines health policy goals. The act essentially attempts to make the individual market function much more like a successful large group market for people above the poverty line. The act also expands Medicaid to cover everyone near or below the poverty line (Jacobs L, 2012). Republicans have had a focus on repealing Obamacare since its inception. The first attempt to fully repeal the bill from law was in 2011 immediately after Republicans gained back control of the House of Rep. The bill, "Repealing the Job-Killing Health Care Law Act," passed in a 245-189 vote with the help of three Democrats, before being voted down in the Senate. In the Senate, the bill was offered as an amendment to an unrelated bill but was voted down. President Obama had stated that he would have vetoed the bill even if it had passed both chambers of Congress.

The National Federation of Independent Business v. Sebelius, 567 U.S. 519 (2012), was a landmark United States Supreme Court decision in which the Court upheld Congress' power to enact most provisions of the Patient Protection and Affordable Care Act (ACA), and the Health Care and Education Reconciliation Act (HCERA), including a requirement for most Americans to have health insurance by 2014. The Acts represented a major set of changes to the American health care system that had been the subject of highly contentious debate, largely divided on political party lines. In March 2010, President Barrack Obama signed the Patient Protection and Affordable Care Act into law. A number of parties sued, including the National Federation of Independent Business, claiming that the sweeping reform law was unconstitutional for various reasons. Following the 2012 Supreme Court ruling upholding ACA as constitutional, Republicans held another vote to repeal the law on July 11; the House of Representatives voted with all 244 Republicans and 5 Democrats in favor of repeal, which marked the 33rd, partial or whole, repeal attempt.

Republicans introduced the bill H.R. 45, an act to repeal the Patient Protection and Affordable Care Act in the United States House of Representatives. The bill H.R. 45 was introduced by Rep. Michele Bachmann (R$\mathrm{MN}$ ) on January 3, 2013. It was referred to multiple House committees and subcommittees, including the United States House Committee on Energy and Commerce. Eric Cantor, the House Majority Leader announced on Friday May 10, 2013 that it would be considered the following week. As of May 15, 2013, H.R. 45 had 123 cosponsors, all of them Republicans.

Strong partisan disagreement in Congress prevented adjustments to the Act's provisions. However, at least one change, a proposed repeal of a tax on medical devices, has received bipartisan support. Some Congressional Republicans argued against improvements to the law on the grounds they would weaken the arguments for repeal. (Blumenthal D, 2014).

In October 2013, Republicans attempted to defund its implementation by refusing to fund the federal government unless accompanied with a delay in ACA implementation, after the President unilaterally deferred the employer mandate by one-year, which critics claimed he had no power to do. The House passed three versions of a bill funding the government while submitting various versions that would repeal or delay ACA, with the last version delaying enforcement of the individual mandate. The Democratic Senate leadership stated the Senate would only pass a "clean" funding bill without any restrictions on ACA. The government shutdown began on October 1. Senate Republicans threatened to block appointments to relevant agencies, such as the Independent Payment Advisory Board and Centers for Medicare and Medicaid Services.

Republicans made a new plan to not only repeal the ACA, but to replace it as well. In less than two months later, a plan was proposed which led to bipartisan outrage. While Republicans argued it cost too much, Democrats believed it did too little.

On February 3, 2015, the House of Representatives added its 67th repeal attempt which also failed vote to the record (239 to 186). This attempt also failed.

On October 23, 2015, the House passed the Restoring Americans' Healthcare Freedom Reconciliation Act of 2015] under the FY2016 budget reconciliation process, which was to prevent the possibility of a filibuster in the Senate. The bill was to partially repeal the provisions of the Affordable Care Act and restrict the federal 
government from operating health care exchanges. It took out funding for subsidies to help lower and middleincome individuals afford insurance through the health care exchanges, eliminated tax penalties for individuals who do not purchase health insurance and employers with 50 or more employees who do not provide insurance plans. It also eliminated taxes on medical devices and the so-called "Cadillac tax" on the most expensive health care plans and phased out an expansion of Medicaid over a two-year period of the bill because it did not completely repeal the Affordable Care Act.

In December of 2015, the Senate passed an amended version of the healthcare reconciliation bill, sending it back to the House, which was passed by the House on January 6, 2016, and vetoed by President Obama on January 8. The House failed to override the President's veto on February on a vote of 241-186, which did not meet the required two-thirds supermajority.

The Congressional Budget Office submitted its report on the estimated impact on insurance coverage and premiums with the repeal of ACA through H.R. 3762 in January 2017 called the Restoring Americans' Healthcare Freedom Reconciliation Act of 2015. (Andrew T, 2017),

On January 12, 2017, the Senate voted 51 to 48 to pass an FY2017 budget resolution, S.Con.Res. 3, which allowed the repeal of the Affordable Care Act through the budget reconciliation process. Despite efforts during the vote-a-rama ${ }^{1}$ that continued, Democrats could not prevent the GOP from going forward with its repeal plans. a big part of his entire 2016 campaign promising to repeal and replace Obamacare. Weeks away from his inauguration, he expressed his desire in doing just that and urged his fellow Republicans to be cautious in their efforts.

Donald Trump was sworn in as President of the United States on January 20, 2017. He signed an executive order on his first day in office, which according to the then White House Press Secretary Spicer, would "ease the burden of Obamacare as we transition from repeal and replace". (Jost, Timothy, 2017)

By March 6, 2017, House Republicans presented a replacement for the ACA. The bill was brought to the House and Senate under the rules of the budget reconciliation process, by which one bill each year is immune to a Senate filibuster so long as it meets certain requirements related to the budget. The text of the AHCA was first made available on March 9, 2017. The text was a plan that was intended to repeal major parts of the ACA, including the Medicaid expansion, but it also kept major parts of the ACA intact, such as the exchanges. since it was immune to a filibuster only 51 votes were needed in the Senate rather than 60 .

The bill was later withdrawn on March 24, 2017 after it was certain that the House would fail to get enough votes to pass it.

On May 4, 2017, the United States House of Representatives voted to pass the American Health Care Act which was to thereby repeal most of the Affordable Care Act by a narrow margin of 217 to 213, sending the bill to the Senate for deliberation. The Senate decided to write their own version of the bill, instead of voting on the House version then on June 22, the Better Care Reconciliation Act of 2017 was unveiled. (C. Stephen, 2017)

The United States Senate voted to proceed with the debate on the American Health Care Act On July 25, 2017. The Senate, largely along party lines voted 50-50 with the Republicans for and the Democrats against proceeding, requiring Vice President Pence to cast the tie-breaking vote. Senator Susan Collins of Maine and and Senator Lisa Murkowski of Alaska (both Republicans) voted against the motion (Shindler,, 2017).

On July 27, 2017, the "skinny repeal" officially known as the Health Care Freedom Act, was introduced. This Act was to repeal the Affordable Care Act's mandate that all Americans carry coverage. The bill included a three-year repeal of the medical device tax and a one-year defunding of Planned Parenthood. The bill was defeated by 49-51, with Republican senators Susan Collins, John McCain, and Lisa Murkowski voting against it along with all the Democrats and Independents.

\footnotetext{
${ }^{1}$ a proceeding in which each amendment was considered and voted upon for about 10 minutes each until all 160 were
} completed 
An amendment to the American Health Care Act, commonly known as Graham-Cassidy, sponsored by Lindsey Graham of South Carolina, with Bill Cassidy of Louisiana as a co-sponsor was submitted On September 13, 2017. The other three co-sponsors were to the bill were Roy Blunt, Dean Heller and Ron Johnson. The amendment was aimed at repealing the Affordable Care Act (ACA) and also to return control of the Medicaid program to the states and cap the program's funding by taking money provided under the Affordable Care Act for insurance subsidies and the expansion of Medicaid and sent it to states in the form of block grants. The amendment also was to redistribute federal money differently to different states, with some states that expanded Medicaid under the ACA (which are generally Democratic) losing federal money to states that did not (which are generally Republican). Senate Majority Leader Mitch McConnell announced on September 26, 2017 however that the Senate had decided not to vote on the Graham-Cassidy bill.

According to Mathews (2019), a reporter for The World Street Journal in Los Angeles, ACA has left a remarkable impact on everything health related within the U.S. health-care system despite the fact that it is 'still a political football.' This report suggests that after almost a decade, ACA has provided healthcare insurance to almost 20 million persons. ACA dropped the percentage of people without health care coverage as shown in the chart below. From the year ACA was birth in 2010 the number of uninsured nonelderly Americans (ages 0-64) reduced from 46.5 million in 2010 to almost below 27 million in 2016. Nevertheless, this chart shows that in 2017 and 2018 the number of uninsured Americans rose by almost 500, 000 persons, but this uninsured rate remains 'significantly below pre-ACA levels' (Tolbert, Orgera, Singer, \& Damico, 2020).

Figure 1

\section{Number of Uninsured and Uninsured Rate Among the Nonelderly Population, 2008-2018}

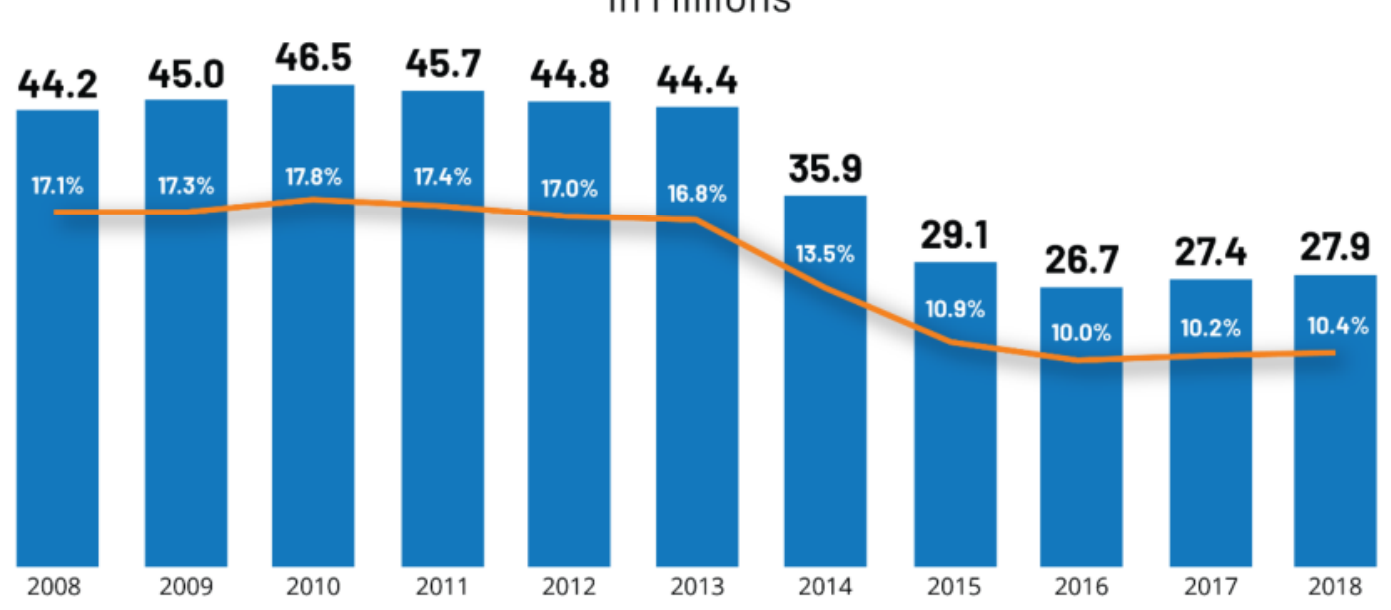

Source: KFF analysis of 2008-2018 American Community Survey, 1-Year Estimates

However, despite these, ACA remains a 'political flashpoint' as it is confronted with a new legal case led by a group of republicans who are backed by the Trump administration that 'aims to strike it down' (Mathews, 2019). This report equally reveals that, this lawsuit will be the sixth encounter that ACA will have before the Supreme Court. The executive vice president at the Kaiser Family Foundation, Larry Levitt says "One of the overarching themes of the ACA has been that it was created amid such partisan rancor... That has colored almost everything that has happened with the ACA since its passage" (Mathews, 2019). The consequences of this attacks on ACA is that, although millions of people became insured under the ACA program, the recent trends reveals that insurance coverage gains are eroding as 27.4 million persons lacked health care coverage in 2018, which is an increase of 1.2 million from 2016 (Tolbert, et al., 2020). 


\section{Conclusion}

Amidst these lawsuits, one of the reasons that the ACA law still survives for this long is because its impact (data) can be tracked overtime, which portrays a picture of how the ACA law truly is based on a decade research (Lagasse, 2019). Consequently, in July 2019, 'House Speaker Nancy Pelosi (D., Calif.) and Senate Minority Leader Chuck Schumer (D., N.Y.) defend protections for people with pre-existing conditions under the ACA' (Mathews, 2019). Former Vice President Joe Biden, a democratic candidate for president still supports ACA and intends to 'strengthen it and expand insurance access by adding a public option to the law -- pitting governmentrun insurance in the marketplace alongside offerings from private insurance companies' (Lagasse, 2019). However, according to Lagasse (2019) "Whether Trump wins re-election or is replaced by a Democratic contender, changes are likely coming to the healthcare system, and it's unclear where -- if anywhere -- the ACA will fit into the new paradigm".

\section{REFERENCES}

"Text - H.R.3762 - 114th Congress (2015-2016): Restoring Americans' Healthcare Freedom Reconciliation Act of 2015". Library of Congress. October 23, 2015.

Jost, Timothy Stoltzfus, Lazarus, Simon. (2017) Trump's Executive Order on Health Care — Can It Undermine the ACA if Congress Fails to Act? New England Journal of Medicine:13, 1201-1203.

Jacobs LR, Skocpol T (2012). Health care reform and American politics: what everyone needs to know. Oxford University Press, 2012

"Legal Challenges to the Affordable Care Act". Healthcare Financial Management Association. Healthcare Financial Management Association.

Buettgens M, Garrett B, Holahan J (2010). America under the Affordable Care Act. Urban Institute. www.urban.org/publications/412267.html

Blumenthal D, Collins SR (2014). Health care coverage under the Affordable Care Act--a progress report. N Engl J Med; 371:275-81

Wilensky GR (2016). What would a Republican win mean for health policy? N Engl J Med;375:1312-1313

Oberlander J (2016) Implementing the Affordable Care Act: the promise and limits of health care reform. J Health Polit Policy Law 41:803-826

Ravi B. Parikh, Alexi A. Wright. (2017) The Affordable Care Act and End-of-Life Care for Patients with Cancer. The Cancer Journal 23:3, 190-193.

Cauchi, Richard (June 28, 2012). "State Legislation and Actions Challenging Certain Health Reforms, 20112012". National Conference of State Legislatures.

Congressional Budget Office. CBO's May 2013 estimate of the effects of the Affordable Care Act on health insurance coverage. CBO, 2013. www.cbo. gov/sites/default/files/cbofiles/attachments/43900-2013-05ACA.pdf

Snell, Kelsey (October 23, 2015). "House passes Obamacare repeal that could be in trouble in the Senate". The Washington Post. ISSN 0190-8286.

C. Stephen Redhead and Janet Kinzer ( 2017), Legislative Actions to Repeal, Defund, or Delay the Affordable Care Act (PDF) (R43289), Congressional Research Service, p. 23,

Andrew Taylor (2017), Congress presses ahead on dismantling health care law, St. Louis, MO: St. Louis Today via Associated Press.

Shindler, Michael (July 28, 2017). "Repeal of Obamacare Goes Down in Flames". The American Conservative.(Case 3:10-cv-00188-HEH, Document 1. Page 5) retrived from http://online.wsj.com/public/resources/documents/032310cuccinellicomplaint.pdf

Obamacare: what the Affordable Care Act means for patients and physicians Mark A Hall, Richard Lord. State of the art review. Center for Bioethics Health and Society, Wake Forest University, Winston Salem, NC 27157-1063.

Lagasse, J. (2019, December 31). Ten years of the Affordable Care Act comes to a close: A look back, and what to expect in 2020. Retrieved January 14, 2020, from https://www.healthcarefinancenews.com/news/tenyears-affordable-care-act-comes-close-look-back-and-what-expect-2020.

Mathews, A. W. (2019, December 18). The Affordable Care Act's Legacy, Nearly 10 Years Later. Retrieved January 14, 2020, from https://www.wsj.com/articles/the-affordable-care-acts-legacy-nearly-10years-later-11576630806.

Tolbert, J., Orgera, K., Singer, N., \& Damico, A. (2020, January 8). Key Facts about the Uninsured Population. Retrieved January 14, 2020, from https://www.kff.org/uninsured/issue-brief/key-facts-about-theuninsured-population/. 